\title{
Questions for TOS Members
}

\section{BEGIN MY TERM as President of The Oceanography} Society (TOS) by first thanking the membership for giving me this chance to serve, and then by recognizing the outstanding leadership of our past president, Dr. Richard Spinrad, for effectively navigating TOS through some turbulent waters. The challenges, however, continue to abound. There is an old curse that says, "May you live in interesting times," and it certainly applies to the world we live in today. Recently, there is one word that dominates the headlines of newspaper front pages-and that is "crisis." Of late, these crises have included global warming, global energy shortages, and global financial meltdowns. However, these crises bring with them opportunities, and it is the exploration of these opportunities that I wish to consider through a dialogue with TOS members.

The "flat" world has undergone staggering changes in the last few years. For example:

- Economic might and energy independence have joined military power as forces assuring future national security and health of a nation.

- Global warming and other climate changes, as well as environmental degradation and loss of biological diversity, are topics that now dominate debates among average citizens and politicians rather than just those of research scientists and environmentalists.

- There is recognition and even acceptance that the public education system as well as higher education are losing their competitive edge in preparing future generations to tackle the challenges of a changing world.

- The consequences of the ever-increasing world population are now confronting many nations as they fail to feed and protect their own people.

With these and other powerful dynamic factors at work, the question I have for TOS membership is: Have we as a community of ocean scientists done what we need to do to guarantee that the extraordinary powers of our most dominant natural resource, the ocean, are brought to bear on major societal concerns? And an even more important question is: Have we as a community of ocean scientists effectively positioned ourselves to be as responsive as we can to the needs of society? My answer to both of these questions is: No. I offer the stagnant federal funding for ocean science research and the meagerness of university support for our academic programs as evidence for my conclusion.

There are many reasons why the field of ocean sciences finds itself in its current state of marginal support-at the very time when we have tremendous contributions to make to the national dialogue. After all, a healthy economy and a healthy environment go hand in hand. Ocean scientists have contributions to make to both environmental stewardship activities for conserving and managing natural resources, and to environmental assessment/prediction for increasing capabilities to safeguard life and property. I suggest that we, as an ocean sciences community, need to better connect to society at large and make ourselves more relevant. In a democracy where discretionary spending is controlled by the political powers, it is not possible to separate federally supported science and politics. Therefore, it is incumbent upon the ocean sciences community to define the scientific enterprise in terms that the public and policymakers can appreciate, and we must supply reasoned arguments for the competitive position of our science funding with respect to other expenditures that clearly support the public good. As Abraham Lincoln once said, "Public sentiment is everything. With public sentiment, nothing can fail; without it, nothing can succeed." Herein is our opportunity-to energize The Oceanography Society membership to meet the challenge of bringing to bear on the relevant concerns of society the incredible powers of the ocean and the bright minds of the ocean sciences community.

I look forward to exploring this topic further in subsequent issues of Oceanography and encourage your involvement in this dialogue.

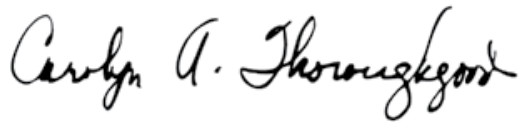

CAROLYN THOROUGHGOOD TOS PRESIDENT 